\title{
CPEB2 Is Necessary for Proper Porcine Meiotic Maturation and Embryonic Development
}

\author{
Barbora Prochazkova ${ }^{1,2}$, Pavla Komrskova ${ }^{2}$ and Michal Kubelka ${ }^{2, *}$ \\ 1 Department of Veterinary Sciences, Czech University of Life Sciences, Kamycka 129, \\ 16500 Prague, Czech Republic; Barbora.Prochazkova@eli-beams.eu \\ 2 Institute of Animal Physiology and Genetics, Czech Academy of Sciences, Rumburska 89, \\ 27721 Libechov, Czech Republic; pavla.komrskova@gmail.com \\ * Correspondence: kubelka@iapg.cas.cz; Tel.: +42-315-639-591
}

Received: 27 July 2018; Accepted: 9 October 2018; Published: 12 October 2018

\begin{abstract}
Oocyte meiotic maturation and embryogenesis are some of the most important physiological processes that occur in organisms, playing crucial roles in the preservation of life in all species. The post-transcriptional regulation of maternal messenger ribonucleic acids (mRNAs) and the post-translational regulation of proteins are critical in the control of oocyte maturation and early embryogenesis. Translational control affects the basic mechanism of protein synthesis, thus, knowledge of the key components included in this machinery is required in order to understand its regulation. Cytoplasmic polyadenylation element binding proteins (CPEBs) bind to the $3^{\prime}$-end of mRNAs to regulate their localization and translation and are necessary for proper development. In this study we examined the expression pattern of cytoplasmic polyadenylation element binding protein 2 (CPEB2) both on the mRNA (by real-time quantitative reverse transcription polymerase chain reaction, qRT-PCR) and protein (by Western blotting, WB) level, as well as its localization during the meiotic maturation of porcine oocytes and early embryonic development by immunocytochemistry (ICC). For the elucidation of its functions, CPEB2 knockdown by double-strand RNA (dsRNA) was used. We discovered that CPEB2 is expressed during all stages of porcine meiotic maturation and embryonic development. Moreover, we found that it is necessary to enable a high percentage of oocytes to reach the metaphase II (MII) stage, as well as for the production of good-quality parthenogenetic blastocysts.
\end{abstract}

Keywords: oocyte maturation; embryonic development; translational control; CPEBs; CPEB2

\section{Introduction}

The meiotic maturation of female germ cells, also known as oocytes, is characterized by the virtual absence of transcription. Therefore, the accumulation of all the necessary RNAs during oocyte growth is crucial for proper meiotic maturation and early embryonic development. In other words, early development is directed by maternally inherited mRNAs, which are synthesized and stored during the long period of oogenesis.

The main regulatory mechanisms of gene expression in oocytes therefore include the post-transcriptional modifications of mRNAs, which affect their translation. Translational regulation is partly controlled by changes in mRNA poly(A) tail length. Cytoplasmic polyadenylation mediates the translational activation, whereas poly(A) tail shortening from a defined starting point acts as a timer of mRNA degradation or silencing. Length control of mRNAs $3^{\prime} U T R$ is important for numerous reasons. Translational regulation through cytoplasmic polyadenylation and deadenylation is essential for the meiotic maturation of oocytes. The correct balance between them is also critical for proper division. In fact, the sequential waves of polyadenylation and deadenylation drive the meiotic progression 
forward, preventing the incorrect timing of specific protein translation during particular maturation phases in oocytes. Default deadenylation in maturing oocytes could be a means to liberate components of the translation apparatus for the synthesis of meiosis-specific proteins [1-8].

The timely, specific expression of mRNAs is generally regulated by the variety of RNA-binding proteins. The most important of them are the cytoplasmic polyadenylation element binding proteins (CPEBs), which, in concert with other RNA-binding proteins, modulate the poly(A) tail length of mRNAs [9]. The specific poly(A) tail elongation and shortening are mediated by interactions of CPEBs with cis elements in mRNAs, namely the cytoplasmic polyadenylation element (CPE) [10]. The classical (canonical) CPE is defined as UUUUUAU; however, Du and Richter [11] revealed possible variations in this sequence.

Four $C P E B$ genes have been described in vertebrates (CPEB1-4), whereas only two CPEBs were identified in Drosophila (Orb1-2). CPEB1 and Orb1 genes are classified in a separate CPEB subfamily. Other members- $C P E B 2, C P E B 3, C P E B 4$, and Orb2-belong to the CPEB2 subfamily. Moreover, they are paralog proteins that are homologous among themselves. The homology between the CPEB proteins is limited to their C-terminal region, which contains two RNA-recognition motif (RRM) domains and one zinc finger structure. In contrast, the N-terminus differs greatly [12-15].

CPE-binding protein 1 (CPEB1) is one of the most studied RNA-binding proteins. It is well known as a polyadenylation promoter. CPEB1 was first described in Xenopus oocytes, where it is involved in the regulation of maturation [10]. It has also been reported to be an important factor for the regulation of the synaptic function of the mouse brain [16].

During female meiosis, CPEB1 plays a significant role in the formation of the synaptonemal complex through the regulation of the mRNAs for SCP1 and SCP3. CPEB1 phosphorylation initiates the translation of cyclin $B 1$ and mos proto-oncogene (c-mos) mRNAs, which are essential for the progression to MII stage oocyte and the establishment of cytostatic factor (CSF) mediated arrest [17]. CPEB1 was later reported to be involved in the regulation of several of the initial embryonic mitotic divisions as well as cell cycle progression [18-22].

Like CPEB1, the proteins from the CPEB2 subfamily participate in translational regulation. They bind CPEs and other recognition elements in the $3^{\prime}$-UTR of specific target mRNAs [12]. The specific binding of CPEB2 to a CPE has been verified by a lack of binding to an mRNA fragment without a CPE, as well as by the fact that CPEB2 binding to the CPE-containing fragment occurred with homopolymeric poly(U) RNA, but not with poly(A) or poly(C) $[23,24]$. As an example, in the case of hypoxia inducible factor 1, subunit $\alpha$ (HIF-1 $\alpha$ ) mRNA, the sequence in the 3'UTR, to which the CPEB2 probably binds, is UUUUCAU [25]. In the case of this mRNA, another type of regulation of translation through CPEB2 has been described. CPEB2 slows down the elongation phase of HIF-1 $\alpha$ translation by connection with the eukaryotic elongation factor eEF2 [25].

The proteins from the CPEB2 subfamily are expressed abundantly and are generally present in the nervous system and in the germline. CPEB3 is expressed in the brain [13], while CPEB4 is abundant in oocytes and early embryos [26]. In mice, CPEB2 mRNA is profusely expressed in male germ cells (its mRNA being first detected in post-meiotic early spermatids) and the brain, but it can be detected by RT-PCR in all tested mouse tissues, including ovarian tissue. CPEB2 is also detected in the cytoplasm of HeLa cells [27]. Moreover, Johnson et al. [28] demonstrated that the regulation of CPEB2 mRNA splicing is a key mechanism in anoikis resistance and a driving force in triple negative breast cancer metastasis. However, the importance of CPEB2 in female reproduction processes has not yet been explored.

To extend the knowledge of the roles that CPEB-related proteins play in reproduction, we focused on the expression and function of CPEB2 during porcine meiotic maturation and early embryonic development. 


\section{Results}

2.1. Expression of CPEB2 $m R N A$ during Meiotic Maturation of Porcine Oocytes and Early Embryonic Development

The expression of CPEB2 mRNA during the meiotic maturation of porcine oocytes and embryonic development was studied by qRT-PCR. We used a set of primers towards the central part of CPEB2 open reading frame (ORF). The relative positions of all primers used in this work are specified in Supplementary Figure S1. During the meiotic maturation, the amount of CPEB2 mRNA increased gradually between GV (germinal vesicle), GVBD (germinal vesicle breakdown), and MI (metaphase I) phases, reaching a maximum in the latter phase. After the MI phase, the expression of CPEB2 mRNA dropped sharply. After parthenogenetic activation, CPEB2 mRNA levels decreased to reach a local minimum at the two-cell stage. The levels of CPEB2 mRNAs rose from the two-cell to the four-cell stage before decreasing to barely detectable levels in the blastocyst stage (Figure 1).

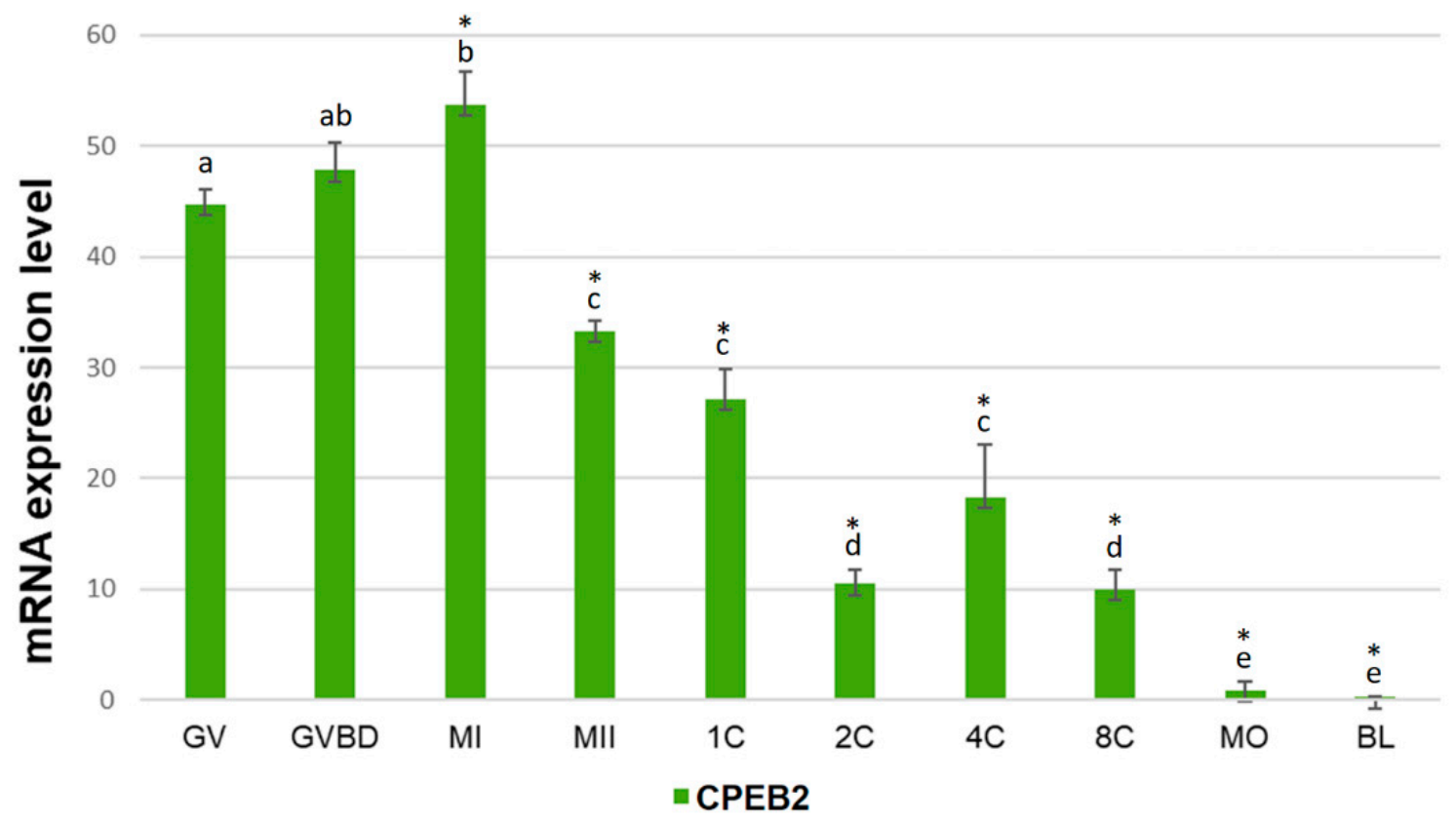

Figure 1. Expression of CPEB2 mRNA during oocyte maturation and early embryonic development. The relative abundance CPEB2 mRNA was determined by qRT-PCR in porcine oocytes and parthenogenetic early embryos including GV, GVBD, MI, and MII oocytes, pronuclear (1C), two-cell (2C), four-cell (4C), eight-cell (8C), morula (MO), and blastocyst (BL) embryos. CPEB2 transcript levels were normalized relative to the abundance of GAPDH mRNA (exogenous control) and are shown as means \pm SEM ( $n=4$ independent biological experiments). Different letters indicate statistical difference $(p<0.05), *$ indicates statistical difference compared to the mRNA level in the GV stage $(p<0.05)$.

Using a different set of primers, which enabled the amplification of the almost full-length ORF for RT-PCR (Figure S1), we detected two splice variants of CPEB2 transcript to be present in porcine oocytes (Figure 2). The length of the observed PCR products corresponds to the CPEB2 variants A and B, which were previously published in NCBI $[29,30]$. CPEB2A is a shorter variant that lacks 90 nucleotides in the coding region and encodes a $47.6 \mathrm{kDa}$ protein in comparison to $\mathrm{CPEB} 2 \mathrm{~B}$, which encodes a $50.8 \mathrm{kDa}$ protein. However, the partial sequencing confirmed only the mRNA corresponding to the longer CPEB2B splice variant to be present in porcine oocytes (data not shown). 


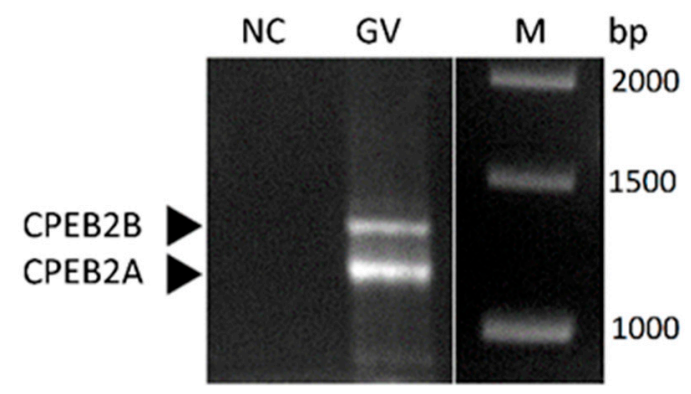

Figure 2. Two splice variants of CPEB2 transcript in porcine oocytes. CPEB2A (short variant) and CPEB2B (long variant) were detected using RT-PCR. GV = oocyte stage, $\mathrm{NC}=$ negative control, $\mathrm{M}=$ marker, $\mathrm{bp}=$ marker size. The experiment was repeated three times, with 280 oocytes per experiment.

\subsection{Expression of CPEB2 Protein during Meiotic Maturation of Porcine Oocytes}

To investigate the CPEB2 protein expression in porcine oocytes, we used Western blotting with the antibody directed towards the $\mathrm{N}$-terminal region of CPEB2. Regarding the two splice variants, the antibody used for this experiment does not discriminate between CPEB2A and 2B. We detected only one band of approx. $50 \mathrm{kDa}$ in all stages of the meiotic maturation (Figure 3a and Figure S2) with a maximum abundance in the MI stage. The protein remained present until metaphase II, when its expression decreased significantly (Figure 3b).

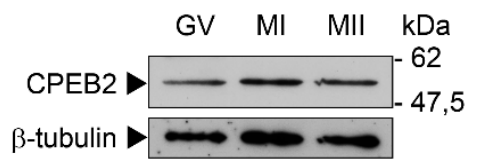

(a)

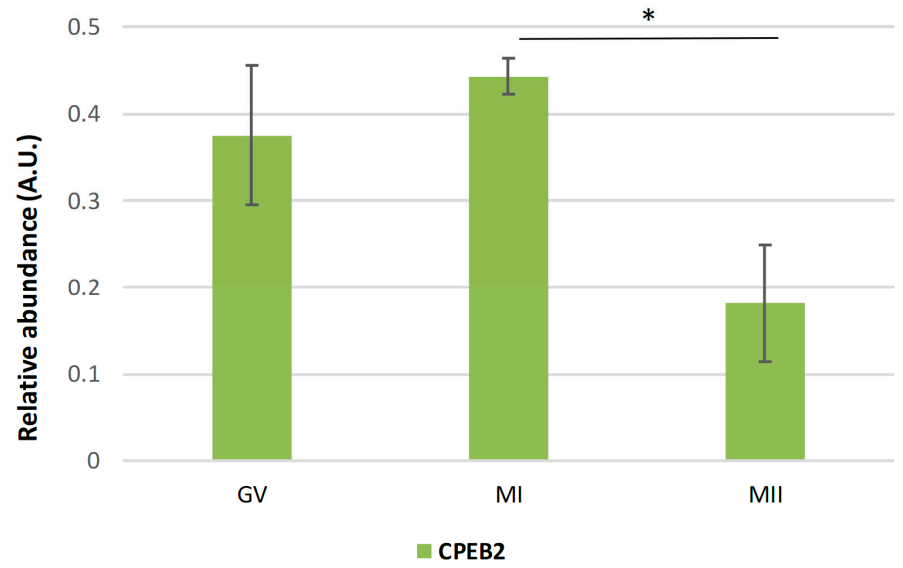

(b)

Figure 3. Relative protein expression of CPEB2 during the meiotic maturation of porcine oocytes. (a) Representative images from WB probed by antibodies for CPEB2 and $\beta$-tubulin proteins in the GV, MI, and MII oocytes. $\beta$-tubulin was used as a loading control. The experiment was performed three times, with 100 oocytes per experiment. (b) The protein expression of CPEB2 from three independent experiments was quantified using Quantity One software. The density of each individual band was normalized to the total density of the examined bands and to $\beta$-tubulin. The value of CPEB2 was summed. The values represent the means \pm SEM and * indicates statistical difference $(p<0.05)$.

We usedTwo-Dimensional Gel Electrophoresis (2DE) Western blotting to investigate possible post-translational modifications of the CPEB2 protein. As shown in Figure 4, three forms of protein with different $\mathrm{pI}$ were present in GV oocytes. We did not observe two distinct signals regarding the molecular weight by this method. After $20 \mathrm{~h}$ of in vitro maturation, we detected another signal with a 
lower pI, possibly representing the phosphorylation of CPEB2 around the time of GVBD (Figure 4, arrow). In metaphase II, all of the CPEB2 forms decreased and only the two most abundant forms were detected. The decrease in metaphase II corresponded to the results of the 1DE Western blot (Figure 3). Using Scansite 3.0 software, three phosphorylation sites of CPEB2 protein were predicted. The four signals could therefore be the different forms of CPEB2 phosphorylation or other post-translational modifications. However, the exact identification of the modifications of CPEB2 will be the subject of further studies.

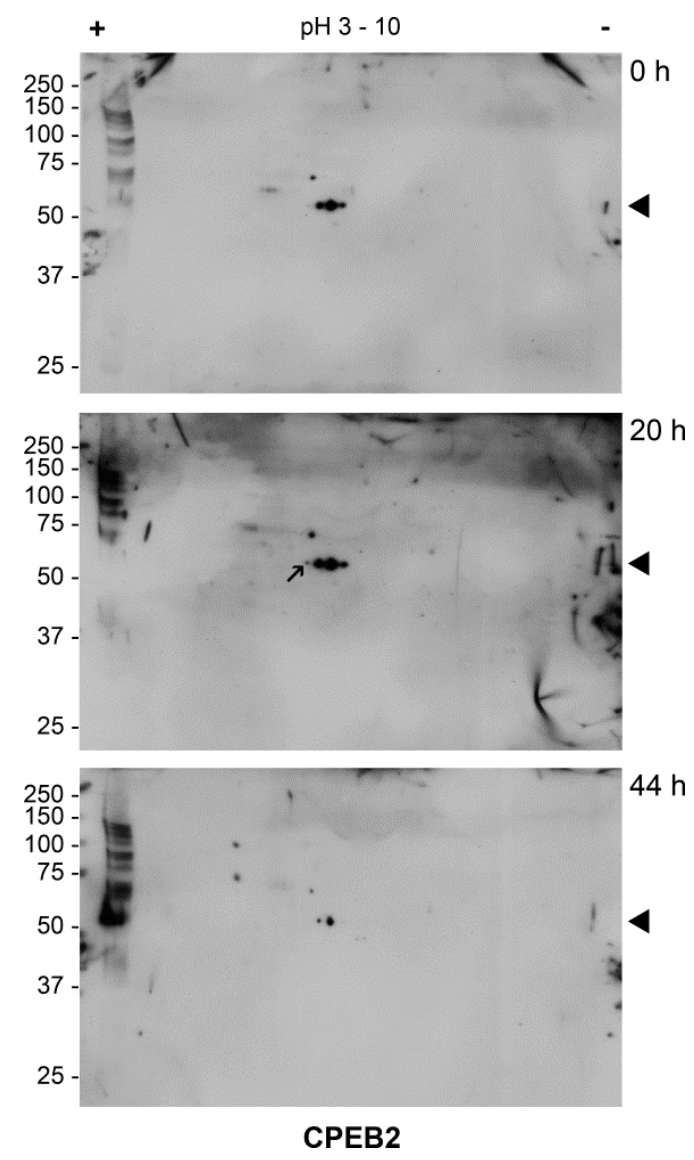

Figure 4. Detection of post-translational modifications of CPEB2 protein by 2DE Western blot. Two hundred immature $(0 \mathrm{~h})$ and matured $(20 \mathrm{~h}$ and $44 \mathrm{~h})$ oocytes were used per sample. Proteins were separated on a gradient of $\mathrm{pH}$ 3-10 using isoelectric focusing in the first dimension and then by SDS-PAGE in the second dimension. The arrow indicates the CPEB2 form with lowest pI. The experiment was performed three times. The black triangle indicates the molecular weight of CPEB2 protein.

\subsection{CPEB2 Protein Moves from Nucleolus to the Cytoplasm}

For the localization of CPEB2 protein we used immunostaining analysis, which revealed that CPEB2 moves from the nucleolus to the cytoplasm. In immature GV oocytes, CPEB2 protein was located in the nucleolus. During maturation in MI and MII stages, CPEB2 co-localized with DNA (Figure 5a) and after parthenogenetic activation it relocated to the cytoplasm in close proximity to the nucleus. This trend persisted in the early developmental stages of embryos until the eight-cell stage, when CPEB2 also started to move into the cytoplasm, away from the nuclei. In the morula and blastocyst stages, CPEB2 expression was significantly stronger and detected throughout the cytoplasm; however, the nuclei were still devoid of CPEB2 accumulation (Figure 5b). 


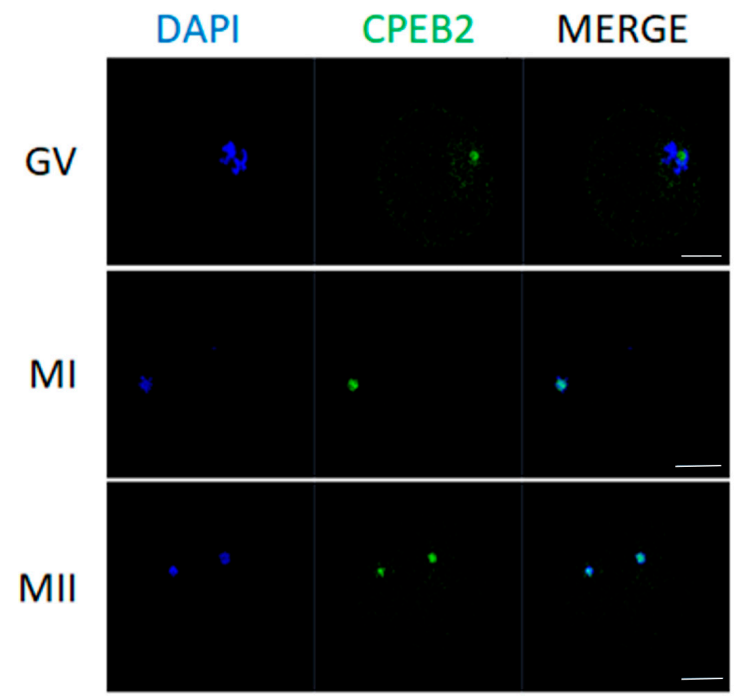

(a)

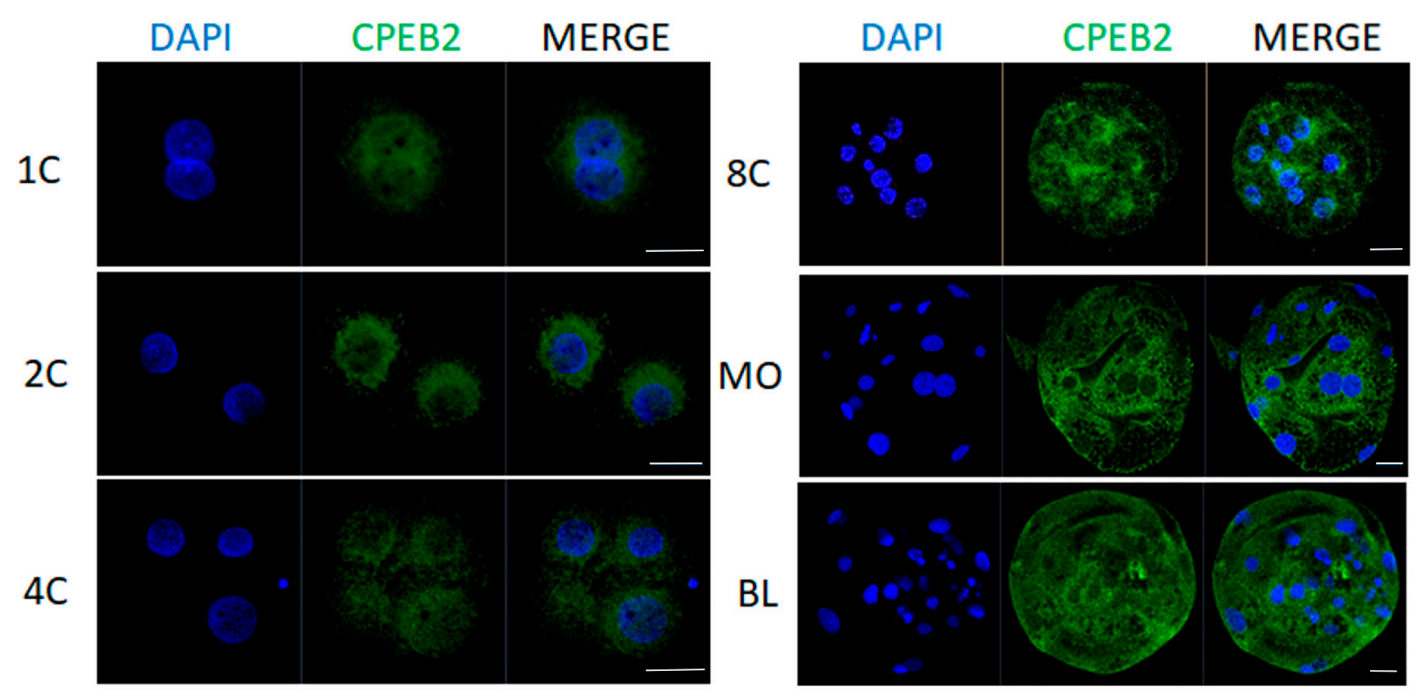

(b)

Figure 5. Localization of CPEB2 protein in porcine oocytes and embryos. (a) Representative confocal images of porcine GV, MI, and MII oocytes. Scale bars = $50 \mu \mathrm{m}$. (b) Representative confocal images of porcine pronuclear (1C), two-cell (2C), four-cell (4C), eight-cell (8C), morula (MO), and blastocyst (BL) parthenogenetic embryos. Scale bars $=100 \mu \mathrm{m}$. A minimum of 50 oocytes and embryos derived from four independent replicates were analyzed. Micrographs show the ICC detection of CPEB2 (green) and DNA (DAPI, blue).

\subsection{CPEB2 Knockdown Resulted in a Decrease of Properly Maturated Oocytes and Properly}

Developed Blastocysts

To elucidate the function of CPEB2 during meiotic maturation and during embryonic development, GV oocytes and parthenotes were microinjected with CPEB2 dsRNA and incubated in the in vitro cultures. The dsRNA efficiency was measured at the mRNA level by qRT-PCR, which showed $88 \%$ and 93\% efficiencies of CPEB2 knockdown (KD) in the MII stage and eight-cell stage, respectively (Figure 6). The effectiveness of CPEB2 KD was also confirmed by ICC in the MII and blastocyst stages (Figure 7). 


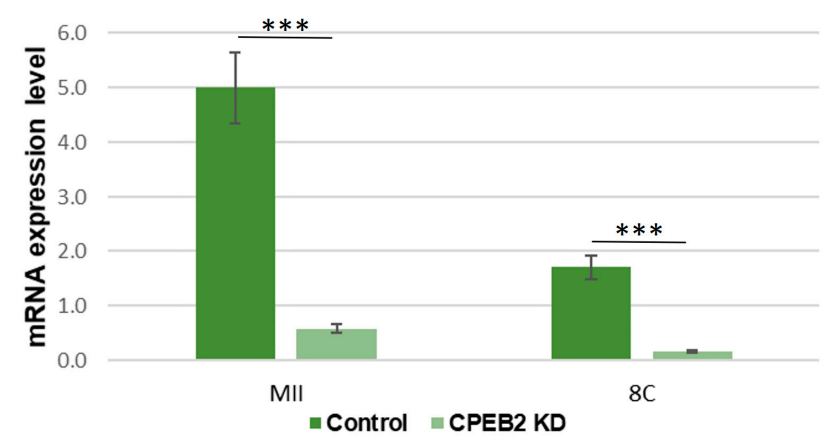

Figure 6. dsRNA efficiency of CPEB2 knockdown (KD) during oocyte maturation and early embryonic development. The relative abundance of CPEB2 mRNA was determined by qRT-PCR in porcine MII oocytes and parthenogenetic eight-cell (8C) embryos. CPEB2 transcript levels were normalized relative to the abundance of GAPDH mRNA (exogenous control) and are shown as means \pm SEM ( $n=4$ independent biological experiments with approximately 100 oocytes/embryos in each group). *** indicates statistical difference $(p<0.001)$.

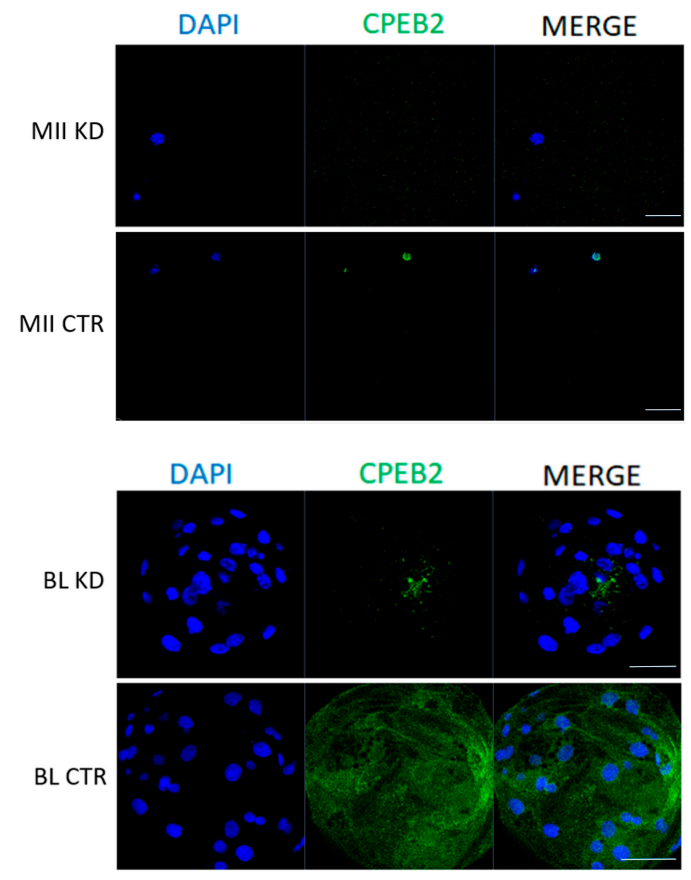

Figure 7. Efficiency of CPEB2 KD during oocyte maturation and embryonic development at the protein level. Representative confocal images show the immunocytochemical detection of CPEB2 (green) protein in porcine MII oocytes and blastocyst (BL). DNA was stained with DAPI (blue). A minimum of 30 oocytes and embryos derived from four independent replicates were analyzed. Scale bars $=100 \mu \mathrm{m}$.

To evaluate the effect of CPEB2 KD on meiotic maturation and early embryogenesis, MII oocyte and embryo developmental rates were examined. The percentage of MII oocytes in the CPEB2 KD group $(43 \%)$ was significantly lower $(p<0.001)$ than that in the control group $(92 \%$, Figure $8 a)$. At the beginning of embryogenesis there were no significant differences between the control groups and the CPEB2 KD groups. In the two-cell stage, $88 \%$ (control) vs. $85 \%$ (KD) developed embryos were observed. However, during the four-cell stage the rate was $75 \%$ vs. $68 \%$ developed embryos, in the eight-cell stage the rate was $65 \%$ vs. $45 \%$, and in the morula stage the rate was $54 \%$ vs. $28 \%$, with all differences being statistically significant $(p<0.001)$. In the blastocyst stage, we also observed significant differences $(p<0.01)$ between the control group $(40 \%)$ and the KD group $(15 \%$, Figure 8 b). 


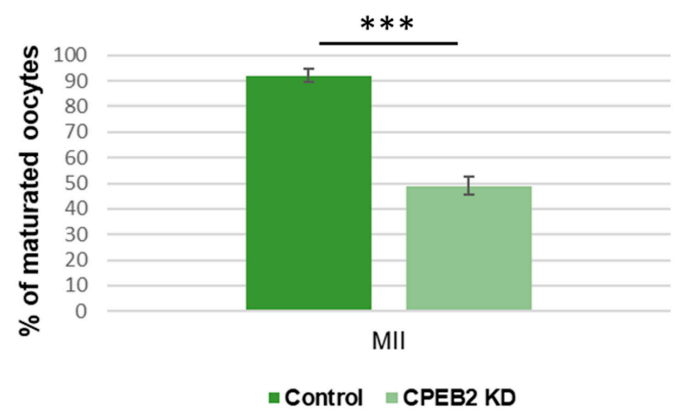

(a)

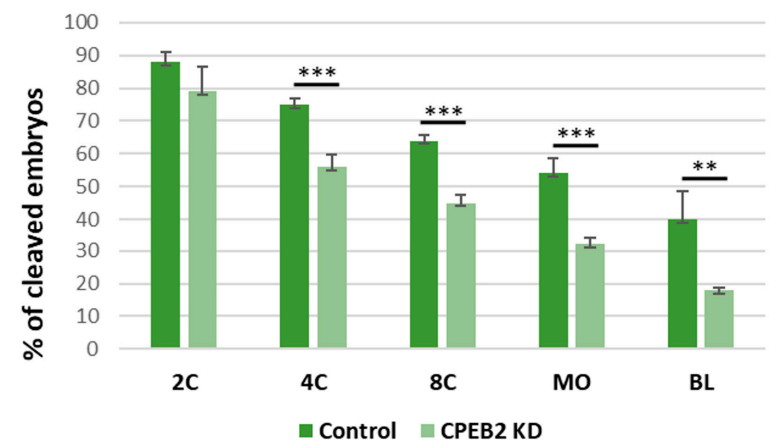

(b)

Figure 8. CPEB2 knockdown by dsRNA resulted in a decrease of properly matured oocytes and properly developed blastocysts. (a) The effect of CPEB2 KD on porcine meiotic maturation. (b) The effect of CPEB2 KD on early porcine embryogenesis including pronuclear (1C), two-cell (2C), four-cell $(4 \mathrm{C})$, eight-cell $(8 \mathrm{C})$, morula $(\mathrm{MO})$, and blastocyst $(\mathrm{BL})$ parthenotes. Data are means \pm SEM $(n=4)$. Asterisks indicate statistical difference $\left({ }^{* *} p<0.01,{ }^{* * *} p<0.001\right)$.

Morphological differences between the control and KD groups were also observed. Not only did the CPEB2 knockdown result in an effective decrease of the first polar body extrusion and blastocyst formation, but also the blastocysts from the CPEB2 KD group were significantly smaller than those in the control group (Figure 9).

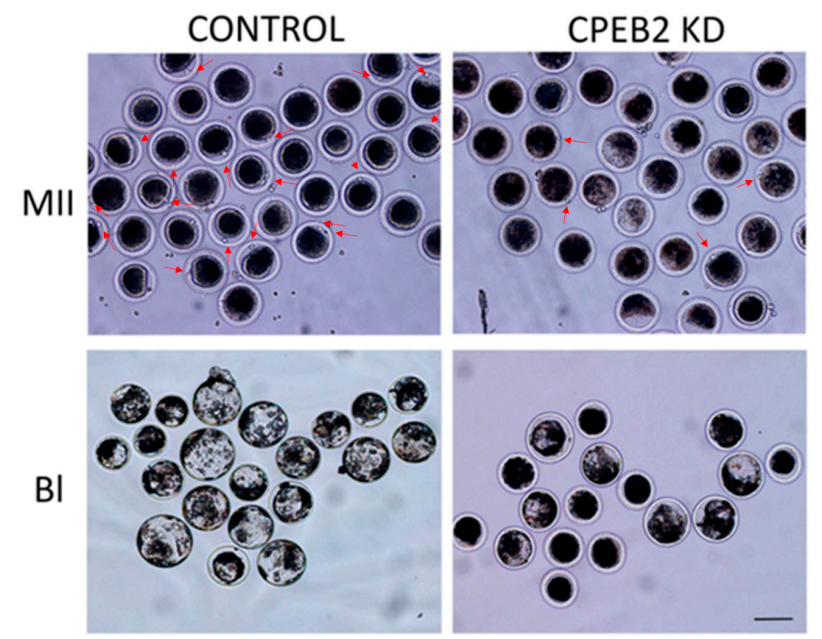

Figure 9. Morphological effect of CPEB2 KD. CPEB2 KD by dsRNA resulted in a decrease of the first polar body extrusion in MII phase porcine oocytes as well as a decrease in porcine parthenogenetic blastocyst formation and size (BL). The red arrows indicate the polar bodies. Scale bar $=200 \mu \mathrm{m}$. 


\section{Discussion}

Cytoplasmic polyadenylation element binding proteins (CPEBs) are a family of proteins that bind to a defined group of mRNAs and regulate their translation. The role of CPEB-mediated translation control has been confirmed in a number of physiological and pathological processes including cell division, germ-cell development, cell differentiation, cellular senescence, synaptic plasticity, learning, and memory [16,31-36].

Apart from a brief description of CPEB2 in the nervous system [24,37] and other tissues [23,25,27], not much is known about its expression and role during oocyte meiosis and early embryogenesis. In this study, we confirmed for the first time the CPEB2 mRNA and protein expression, as well as their localization during meiotic maturation in pig oocytes and during early embryogenesis, and their importance in the regulation of these processes.

We detected two splice variants of CPEB2 mRNA in porcine oocytes. All CPEBs are the subjects of alternative splicing, which results in the expression of more splicing variants [24]. Wang and Cooper [15] analyzed mice and human orthogenes of CPEB1-4 proteins in silico and all possessed a large number of transcription variants, leading to the expression of different isoforms of these proteins. They described two RNA splicing variants of CPEB2 in the cells of the mouse retina. The shorter variant (CPEB2A) is formed by the omission of exon 4 , and is 90 nucleotides less than the longer variant (CPEB2B). Although two variants of CPEB2 are also present in porcine oocytes (Figure 2), the partial sequencing of the PCR products confirmed only the sequence corresponding to the longer (CPEB2B) variant. The sequencing data did not confirm the presence of the CPEB2A variant; however, the shorter variant may be the result of alternative splicing omitting different exons than in the case of CPEB2A. Wang and Cooper [15] also further mentioned the existence of a long CPEB2 transcript, which encodes a protein almost double in size (109.8 kDa in the human and 107.4 kDa in the mouse ortholog). This transcript has a longer coding sequence at the $5^{\prime}$ end, therefore it could not be captured by our proposed primers. The presence of the longer variant in porcine oocytes thus cannot be confirmed or refuted.

Johnson et al. [28] observed antagonism between these two CPEB2 splice variants and hypothesized their opposing functions-CPEB2B may simply act to bind specific mRNAs and block them from associating with CPEB2A, which inhibits mRNA polyadenylation and translation. They also propose a mechanistic explanation, that the inclusion of the additional 30 amino acids in the full-length CPEB2B changes its function, so that the factor now presents the bound RNA for efficient polyadenylation versus inhibiting the polyadenylation when bound to CPEB2A. Although we documented the presence of two CPEB2 isoforms in porcine oocytes at the mRNA level, we detected only one protein signal of the corresponding size (approximately $50 \mathrm{kDa}$ ) using both $1 \mathrm{D}$ and 2D Western blotting. The expected difference in size between CPEB2A and CPEB2B proteins is only 2 to $3 \mathrm{kDa}$. We assume that either the difference is too small to be distinguished under our conditions or only one variant is predominantly expressed in the porcine oocytes. The exact role of the two variants of CPEB2 in porcine oocytes remains to be ascertained.

Wang and Cooper [15] also identified several motifs in the CPEB2 protein, including theoretical phosphorylation sites and the motif that leads to protein interaction with cadherin-1 (CDH1) and cell-division cycle protein 20 (CDC20) components of anaphase-promoting complex/cyclosome (APC/C). This may lead to the degradation of this protein through the ubiquitin-proteasome system, which correlates with our results. The CPEB2 protein was stable until metaphase I, when its partial degradation occurred. This matches with its paralog CPEB1, the degradation of which is necessary for the transition between metaphase I and metaphase II in Xenopus oocytes [19], and which has also been observed also in porcine oocytes [38]. Mendez et al. [19] reported similar results, suggesting that the degradation of CPEB1 is necessary for the transition between metaphase I and metaphases II in Xenopus oocytes. These results are also supported by us using a more sensitive method of qRT-PCR, demonstrating that the relative expression of CPEB2 increases from the GV to the MI stages and 
subsequently decreases. Whether the degradation of CPEB2 after metaphase I is essential for the commencement of metaphase II, similar to the case of CPEB1, is a subject for further study.

We confirmed that CPEB2 is also expressed during early porcine embryogenesis. After parthenogenetic activation, CPEB2 expression is still detectable in all developmental stages and, except for a slight increase in the four-cell stage, continuously decreases. Considering that embryonic genome activation occurs at the four-cell stage in porcine embryos [39], these results suggest that porcine CPEB2 is not just a maternally but also a zygotically expressed gene in the later stages of embryo development.

As regards CPEB2 post-translational modification, we detected four specific signals through 2DE Western blot analysis, which could theoretically correspond to phosphorylation at the presumed phosphorylation sites. This phosphorylation may play a role in CPEB2 binding to mRNA and in the regulation of mRNA translation, similar to the role of phosphorylation in CPEB1 [37]. It may also lead to CPEB2 degradation after metaphase I, as reported above. However, the real character and significance of CPEB2 modifications are yet to be elucidated.

The immunocytochemistry results (Figure 5) show that CPEB2 moves from the nucleolus to the cytoplasm, where it is relocated after parthenogenetic activation. This relocation is probably a response to calcium-mediated signaling and $\mathrm{Ca}^{2+} /$ calmodulin-dependent protein kinase II (CaMKII) activity. CPEB2-4 have conserved nuclear export signals that are not present in CPEB1 [40].

Not much is known about CPEB2 function and its target mRNA interactions; however, due to the similar levels of protein expression, as well as to the similar primary sequences between CPEB1 and CPEB2, it can be envisaged that CPEB2 shares many similar functions with CPEB1. An overlap in RNA binding specificity between CPEB1 and CPEB2 also indicates the interaction of CPEB2 with $\beta$-catenin and (CaMKII) [24], which are both established CPEB1 targets [16,41]. $\beta$-catenin is an important mediator of the WNT pathway. Balanced WNT signaling in germ cells is essential for their proliferation [42] and commitment to meiosis, which suggests a requirement for this pathway in follicle/oocyte functions. Overactive $\beta$-catenin in female germ cells causes abnormal WNT/ $\beta$-catenin signaling, which in turn leads to defects in female fertility [43]. In addition, CaMKII is an important regulator of the meiotic cell cycle and spindle assembly, which may exert its effect via the regulation of M-phase promoting factor (MPF) and mitogen-activated protein kinases (MAPK)/ribosomal protein S6 kinase A1 (p90rsk) activity during the meiotic maturation and activation of pig oocytes. After CaMKII blocking, first polar body emission was inhibited [44]. Due to the fact that CPEB2 interacts with these important meiotic regulators, it can be assumed that poor meiotic maturation in CPEB2 KD oocytes might be a response to the disruption of these mechanisms.

The importance of CPEB-mediated translation regulation during oocyte and sperm development has been clarified by CPEB1 knockout $(\mathrm{KO})$ in a mouse model. These CPEB1 KO mice have no apparent defect in viability but their reproductive organs are reduced (the mice have no detectable ovaries and their testis are 30\% smaller in CPEB1 KO) and both males and females are sterile [45]. Moreover, their oocytes have devastating defects during meiotic maturation [46]. Similarly, Stebbins-Boaz et al. [47] showed that Xenopus oocytes injected with anti-CPEB1 antibodies fail to polyadenylate and activate c-mos mRNA.

However, unlike in the case of CPEB1 knockout mice, CPEB2 KO mice are fertile, although the number of offspring is significantly reduced. During in vitro maturation, only $42 \%$ of the oocytes from these mice are able to reach the MII stage [48], which is consistent with our results for CPEB2 KD porcine oocytes. Nairismägi et al. [49] reported that CPEB2 protein interacts with the TWIST1 transcription factor and negatively regulates its expression. In embryos, TWIST1 mRNA precedes protein expression in epithelial somites and is an essential gene involved in early mesoderm development and dorsal-ventral patterning [50,51]. This could also be the reason for the abovementioned offspring reduction and it can be assumed that only a small percentage of the already low number of well-developed CPEB2 KO/KD porcine blastocysts could further develop. 
The disturbed early embryonic development of CPEB2 KD embryos into the blastocyst stage can also be explained by the potential involvement of CPEB2 in tight junction (TJ) assembly. CPEB-mediated TJ has been previously identified in epithelial cell polarity. Normal cells show strong polarity, prevalent cavity formation, and selective permeability in contrast with CPEB1-deficient cells, which have reduced polarity and cavity formation in addition to increased permeability $[52,53]$. As already documented by Nagaoka et al. [53], CPEB1 plays an important role in regulating the localization of Tjp1 mRNA and thereby in the regulation of cellular tight junctions, which is essential for successful embryonic development. In addition to Tjp1, $\beta$-catenin is also connected to TJ regulation [54]. The hypothesis that CPEB2 regulates tight junction biogenesis during embryonic development remains to be proved by further research.

\section{Materials and Methods}

\subsection{Chemicals}

All chemicals used in this research were purchased from Sigma-Aldrich Chemical Company (St. Louis, MO, USA) unless otherwise noted.

\subsection{Oocyte Collection and In Vitro Maturation}

Porcine ovaries were obtained from gilts at an unknown stage of their estrous cycle from local slaughterhouses (Jatky Český Brod a.s., Český Brod, Czech Republic) and transported to the laboratory within $2 \mathrm{~h}$ after slaughter in a physiological saline $\left(0.9 \%\right.$ sodium chloride) solution at $36-37^{\circ} \mathrm{C}$.

Ovaries were washed three times in fresh physiological saline and then kept at $38^{\circ} \mathrm{C}$ for $15 \mathrm{~min}$. Fully-grown cumulus-oocyte complexes (COCs) were aspirated from follicles (3-6 $\mathrm{mm}$ in diameter) by needle $(0.80 \times 50 \mathrm{~mm}$, Sterican, B. Braun) into a syringe $(10 \mathrm{~mL}$, Lauer solo, B. Braun). COCs were transferred into a 14-mL round tube (SPL, BioLab, Singapore) and precipitated for $15 \mathrm{~min}$ in a water base at $37^{\circ} \mathrm{C}$. After washing three times in HEPES solution, COCs were selected and only oocytes with granulated cytoplasm and compact cumulus mass were collected for further study. Collected oocytes were washed three times in culture medium M199 (Life Technologies, Carlsbad, CA, USA) supplemented with $10 \%$ fetal bovine serum and $0.8 \mathrm{IU} / \mathrm{mL}$ serum gonadotropin and chorionic gonadotropin (P.G. 600, Intervet international GmbH, Unterschleißheim, Germany). For maturation, the oocytes were put into a 4-well dish (SPL, BioLab, Singapore) with the same culture medium mixture and covered with mineral oil and incubated for $20 \mathrm{~h}$ (GVBD stage), $28 \mathrm{~h}$ (MI stage), and $44 \mathrm{~h}$ (MII stage) at $38.5^{\circ} \mathrm{C}$ in a humidified atmosphere of $5 \% \mathrm{CO}_{2}$ in air.

Before sampling for WB and RNA isolation, the oocytes were denuded in HEPES solution supplemented with $1 \mathrm{mg} / \mathrm{mL}$ hyaluronidase, then washed three times in HEPES and once in RNase-free $\mathrm{H}_{2} \mathrm{O}$ and stored at $-80^{\circ} \mathrm{C}$ until use.

\subsection{Parthenogenetic Activation and Embryo Development}

Denuded MII oocytes with obvious first polar bodies $(\mathrm{Pb})$ and uniform ooplasm were selected for parthenogenetic activation. They were washed three times in HEPES, three times in PBS supplemented with $0.1 \%$ BSA (PBS-BSA), and once each in 33\% activation mannitol medium (ACT, $280 \mathrm{mM}$ mannitol solution containing $0.001 \mathrm{mM} \mathrm{CaCl}_{2}$ and $0.05 \mathrm{mM} \mathrm{MgSO}_{4}$ ) in PBS-BSA, $66 \%$ ACT in PBS-BSA, and $100 \%$ ACT. After washing, the oocytes were transferred to a fusion chamber containing two electrodes overlaid with ACT. Membrane fusion was induced by applying two DC pulses of $160 \mathrm{~V} / \mathrm{mm}$ for $60 \mu$ s with an Electro Cell Manipulator 2001 (BTX, Inc., San Diego, CA, USA). The embryos were then washed in $66 \%$ ACT in PBS-BSA, 33\% ACT in PBS-BSA, three times with PBS-BSA solution, and finally in porcine zygote medium-5 (PZM-5). After $3 \mathrm{~h}$ of cultivation in PZM-5 supplemented with $7.5 \mu \mathrm{g} / \mathrm{mL}$ of cytochalasin B, the embryos were washed in PMZ-5 medium containing $0.4 \%$ BSA and then transferred into fresh medium under mineral oil for 1 day (two-cell stage), 2 days (four-cell stage), 
4 days (eight-cell stage), 5 days (morula stage), and 7 days (blastocyst stage) at $38.5^{\circ} \mathrm{C}$ in a humidified atmosphere of $5 \% \mathrm{CO}_{2}$ in air.

Before sampling, the embryos were washed three times in HEPES and once in RNase-free $\mathrm{H}_{2} \mathrm{O}$. They were then stored at $-80^{\circ} \mathrm{C}$ until use.

\section{4. dsRNA Preparation and Microinjections}

Both CPEB2 RNA isoforms were knocked down by a microinjection of CPEB2 dsRNA. Control groups of oocytes and embryos were microinjected with a corresponding volume of sterile nuclease-free $\mathrm{H}_{2} \mathrm{O}$. The porcine CPEB2 dsRNA was amplified in vitro from mRNA of CPEB2. After the construction of primers (dsCPEB2 forward primer: $5^{\prime}$-TAA TAC GAC TCA CTA TAG GGA GAC CAC GAG CTA TCC ACAC CCA GGAA- $3^{\prime}$ and reverse primer: $5^{\prime}$-TAA TAC GAC TCA CTA TAG GGA GAC CAC GGA GAA AGC AAC TCG ACC AG-3'), cDNA was prepared using a Phusion High-Fidelity DNA Polymerase kit (Thermofisher, Deutsch, Germany. In the next step, cDNA was purified using a gel extraction kit (GeneAll Biotechnology, Seoul, Korea). Transcription from PCR products was carried out using a MEGAscript T7 kit (Ambion, Austin, TX, USA) in accordance with the manufacturer's instructions. Then the dsRNA was purified from the DNA template and single-stranded RNAs by treatment with DNase I and RNase A. Purified dsRNA was eluted in RNase-free water. The concentration was determined by measuring the optical density at $260 \mathrm{~nm}$ (Nanodrop, Thermofisher, Deutsch, Germany) and adjusted to a final concentration of $1 \mu \mathrm{g} / \mu \mathrm{L}$ dsRNA aliquots was stored at $-80^{\circ} \mathrm{C}$.

Subsequently, 5-10 pl of dsRNA was microinjected into the cytoplasm of denuded oocytes in the GV stage, or into parthenogenetic zygotes $8 \mathrm{~h}$ post activation. For the injection, Eppendorf FemtoJet microinjector (Eppendorf, Hamburg, Germany) was used together with a Nikon TE2000-U inverted microscope (Nikon Corporation; Tokyo, Japan).

After microinjection, the oocytes were cultured for $24 \mathrm{~h}$ in the standard cultivation medium supplemented with $1 \mathrm{mM}$ dbcAMP. Then the oocytes were washed and cultured further in fresh medium under the same conditions as above. Embryo cultivation was again carried out as already stated. Knockdown efficiency was confirmed by qRT-PCR. All microinjection experiments were performed in quadruplicate, with approximately 100 oocytes/zygotes injected in each group.

\subsection{Evaluation of Oocyte Maturation}

For the evaluation of maturation stages, two methods were used. Oocytes intended for RNA isolation, immunocytochemistry, and MII maturation rates were washed three times in PBS-BSA, stained for $5 \mathrm{~min}$ in $5 \mu \mathrm{g} / \mu \mathrm{L}$ DAPI (D9542) in PBS-BSA, and then washed in PBS-BSA. The maturation stage of each oocyte was checked under UV light.

For samples intended for Western blot and 2DE Western blot, a portion of the oocytes was denuded and fixed in a mixture of ethanol and acetic acid solution (3:1) for $48 \mathrm{~h}$. Staining was performed with $1 \%$ orcein in $50 \%$ aqueous acetic acid and $1 \%$ sodium citrate, after which the oocytes were washed with $40 \%$ acetic acid. Oocytes were observed using phase-contrast microscopy (Carl Zeiss, Jena, Germany) and only samples from cultivations of more than $85 \%$ oocytes at the desired stage were used for further experiments.

\subsection{Western Blotting}

Samples of 100 oocytes were lysed in $10 \mu \mathrm{L}$ of $1 \times$ Reducing SDS Loading Buffer (Cell Signaling Technology, Danvers, MA, USA) by heating at $100{ }^{\circ} \mathrm{C}$ for $5 \mathrm{~min}$. For the separation of proteins, SDS-PAGE was used. Proteins were then transferred to an Immobilon P membrane (Millipore, Bedford, MA, USA) using a semidry blotting system (Biometra GmbH, Goettingen, Germany) for 25 min at $5 \mathrm{~mA} / \mathrm{cm}^{2}$. Membranes were blocked in 5\% skimmed milk dissolved in $0.05 \%$ Tween-Tris-buffer saline (TTBS), pH 7.4 for $1 \mathrm{~h}$. After a brief washing in TTBS, membranes were incubated at $4{ }^{\circ} \mathrm{C}$ overnight with the following primary antibodies: CPEB2 (ARP41186; Aviva System Biology, San Diego, CA, USA), 
monoclonal anti- $\beta$-tubulin antibody (T4026; Sigma-Aldrich). After washing the membranes $3 \times 10 \mathrm{~min}$ in TTBS, incubation with a horseradish peroxidase-conjugated donkey anti-rabbit or anti-mouse IgG antibody (Jackson Immuno Research, Suffolk, UK) followed for $1 \mathrm{~h}$ at room temperature. An chemiluminescent reagent ECL-plus detection system (GE Healthcare, Chalfont St Giles, Bucks, UK) was used for visualization according to the manufacturer's instructions. A GS-800 Calibrated Densitometer (Bio-Rad, Hercules, CA, USA) was used to scan the films and Quantity One 1-D Analysis Software (Bio-Rad) was used for quantification.

\subsection{Two-Dimensional Gel Electrophoresis (2DE)}

Samples containing 200 oocytes were lysed in $30 \mu \mathrm{L}$ of lysis buffer containing $7 \mathrm{M}$ urea, $2 \mathrm{M}$ thiourea, $3 \% w / v$ CHAPS, $2 \% v / v$ Nonidet-P40, and $5 \mathrm{mM}$ TCEP in the presence of inhibitors of proteases and phosphatases (Roche, Basel, Switzerland) and 0.2\% ampholyte (Bio-Rad, Hercules, CA, USA) according to the manufacturers' directions for $15 \mathrm{~min}$ at room temperature. Next, $120 \mu \mathrm{L}$ of rehydration buffer containing $7 \mathrm{M}$ urea, $2 \mathrm{M}$ thiourea, 4\% CHAPS, $200 \mathrm{mM}$ DeStreak, inhibitors of proteases, phosphatases (Roche, Basel, Switzerland), 0.2\% ampholyte (Bio-Rad, Hercules, CA, USA), and $0.5 \%$ bromophenol blue was added and the samples were lysed for $10 \mathrm{~min}$. Isoelectric focusing separation (IEF) was performed on an IEF Cell (Bio-Rad, Hercules, CA, USA) system using the following program: $1 \mathrm{~h}$ to $200 \mathrm{~V}, 1 \mathrm{~h}$ to $500 \mathrm{~V}, 30 \mathrm{~min}$ to $1000 \mathrm{~V}, 30 \mathrm{~min}$ to $4000 \mathrm{~V}$, and $4000 \mathrm{~V}$ until a total of $8 \mathrm{kVh}$ was reached. After IEF separation, the gel strips were equilibrated in $50 \mathrm{mM}$ Tris, $\mathrm{pH}$ 8.8, $6 \mathrm{M}$ urea, 30\% glycerol, 4\% SDS, $100 \mathrm{mM}$ DeStreak, and a trace of bromophenol blue for $25 \mathrm{~min}$. The 2DE was followed by SDS-PAGE and WB.

\subsection{PCR}

Total RNA was isolated from groups of 280 oocytes using an RNeasy Micro Kit (74004; Qiagen, Hilden, Germany. For the reverse transcription, SuperScript III Reverse Transcriptase (Life Technologies) was used. PCR was performed with following primers: CPEB2 forward primer- $5^{\prime}-$ TCA CTA GTT CCT GGG GAG CAA TGC AT- $3^{\prime}$ and reverse primer-5'-GCA CTA GTG TTC CAG CGG AAG TGG AT- ${ }^{\prime}$. cDNA was subjected to electrophoresis on $2 \%$ agarose gel and stained with GelRed (Biotium, Hayward, CA, USA) or ethidium bromide. Gels were observed and photographed using a Kodak Gel Logic 100/200 Camera (Carestream Health, Inc., Rochester, NY, USA), K. G. L. integrated illuminator cabinet (Carestream Health, Inc.), and KODAK MI SE software (v. 4.5.0.; Carestream Health, Inc.).

\section{9. $q R T-P C R$}

For the evaluation of gene expression, mRNA was isolated from 50 oocytes and 25 parthenogenetic embryos (two-cell, four-cell, and eight-cell stages, morula and blastocyst) per group, using a Dynabeads mRNA Direct Kit (61011, Ambion, Life Technologies, CA, USA), and cDNA was synthesized with the HyperScript ${ }^{\mathrm{TM}}$ First-Strand Synthesis Kit (601-005, GeneAll Biotechnology, Seoul, Korea) according to the manufacturer's instructions. For subsequent experiments, a minimum of three replicates of isolated mRNA from each stage were used.

WizPure $^{\mathrm{TM}}$ qPCR Master (Super Green) (W1731, Wizbiosolutions, Seongnam, Korea) was used to provide the real-time quantification of target gene CPEB2 and of GAPDH, as a housekeeping gene. CPEB2 and GAPDH were amplified with specific primer pairs (CPEB2 forward primer: $5^{\prime}-\mathrm{GTT}$ CAG ATC CGT CCT TGG AA- $3^{\prime}$ and reverse primer: $5^{\prime}$-GGA GAA AGC AAC TCG ACC AG- $3^{\prime}$; GAPDH forward primer: 5'-GGG CAT GAA CCA TGA GAA GT-3' and reverse primer: 5'-AAG CAG GGA TGA TGT TCT GG-3') which were designed with Primer Premier 5 (PREMIER Biosoft, CA, USA). qPCR was conducted using the CFX96 Touch Real-time PCR Detection System (Bio-Rad, CA, USA) under the following conditions: denaturation at $95^{\circ} \mathrm{C}$ for $10 \mathrm{~min} ; 40$ cycles of amplification and quantification at $94^{\circ} \mathrm{C}$ for $10 \mathrm{~s}, 60^{\circ} \mathrm{C}$ for $30 \mathrm{~s}$, and $72^{\circ} \mathrm{C}$ for $30 \mathrm{~s}$ with a single fluorescence measurement; melting at $65-95^{\circ} \mathrm{C}$ with a heating rate of $0.2{ }^{\circ} \mathrm{C} / \mathrm{s}$ and continuous fluorescence measurement. Relative 
gene expression was quantified by normalization to GAPDH levels using the $2^{-\Delta \Delta C t}$ method [55]. Four independent experiments were performed with triplicate samples for each stage.

\subsection{Immunocytochemistry (ICC)}

Before staining, the oocytes and embryos were treated for 5-10 s with acidic Tyrode's solution (T1788) to remove zona pellucida. They were then fixed for $30 \mathrm{~min}$ in $3.7 \%$ paraformaldehyde. Next, they were washed three times in PVA-PBS and permeabilized with PVA-PBS containing $0.5 \%$ Triton X-100 for $30 \mathrm{~min}$. For the following washes, washing solution $(0.1 \%$ Triton X-100 $+0.01 \%$ Tween 20 in PBS) was used three times for 5 min. The oocytes and embryos were blocked in 1\% BSA in PBS for $1 \mathrm{~h}$ and then incubated overnight at $4{ }^{\circ} \mathrm{C}$ in the same solution with the addition of the anti-CPEB2 antibody (dilution 1:50, sc-55622, Santa Cruz, Dallas, TX, USA). In the next step, the oocytes were washed with washing solution for $5 \mathrm{~min}$ and then treated with goat anti-rabbit secondary antibody (1\% BSA in PBS containing Alexa-Fluor-488, dilution 1:200) for $1.5 \mathrm{~h}$. After washing in washing solution, oocytes and embryos were incubated with $10 \mathrm{mg} / \mathrm{mL}$ DAPI in PVA-PBS for $10 \mathrm{~min}$ in the dark, washed three times in PVA-PBS, and mounted onto glass slides with mounting media Vectashield (94010, Vector Laboratories, Burlingame, CA, USA) and examined using a confocal microscope (Zeiss LSM 710 META, Jena, Germany). Images were processed using Zen software (version 8.0, Zeiss, Jena, Germany).

\subsection{Statistical Analysis}

Data were analyzed using SPSS software version 11.0 (SPSS Inc., Chicago, IL, USA). Differences in normalized data across meiotic maturation and developmental stages were determined by one-way ANOVA. Individual mean comparisons were performed using Fisher's least significant difference (LSD) method. Differences between CPEB2 control and CPEB2 KD groups were statistically analyzed by an independent two-sample Student's $t$-test. Data are presented as averages \pm SEM. The values indicated by asterisks are significantly different $\left({ }^{*} p<0.05,{ }^{* *} p<0.01\right.$, and $\left.{ }^{* * *} p<0.001\right)$.

\section{Conclusions}

For the first time, we have described the expression of CPEB2 at both mRNA and protein levels, as well as its localization during the meiotic maturation of porcine oocytes and during early embryogenesis. Our results indicate that there are two RNA isoforms of CPEB2 in porcine oocytes and that CPEB2 is likely to be post-translationally modified, possibly by phosphorylation. The level of CPEB2 mRNA expression changes during meiotic maturation and early embryogenesis and likely plays an important role for their successful completion, since CPEB2 knockdown by double-stranded RNA reduces the rate of the meiotic maturation of oocytes as well as the rate of development to the blastocyst stage and the blastocyst size.

Further studies will be required to determine how CPEB2 is involved in the signaling pathways regulating meiotic maturation and early embryonic development in addition to which genes it directly affects.

Supplementary Materials: Supplementary materials can be found at http://www.mdpi.com/1422-0067/19/10/ 3138/s1.

Author Contributions: Conceptualization, B.P., P.K., and M.K.; Methodology, B.P. and P.K.; Software, B.P.; Validation, B.P., P.K., and M.K.; Formal Analysis, B.P.; Investigation, B.P.; Resources, B.P.; Data Curation, B.P.; Writing-Original Draft Preparation, B.P.; Writing-Review and Editing, P.K. and M.K.; Visualization, M.K.; Supervision, M.K.; Project Administration, M.K.; Funding Acquisition, M.K.

Funding: This research was supported by grant from the Czech Science Foundation 15-22765S (http:/ / www.gacr. $\mathrm{cz} /$ ). M.K was also supported by the grant EXCELLENCECZ.02.1.01/0.0/0.0/15_003/0000460 OP RDE.

Acknowledgments: We thank Jaroslava Supolikova and Marketa Hancova for their exceptional assistance with experiments.

Conflicts of Interest: The authors declare no conflict of interest. 


\section{Abbreviations}

1C one-cell embryo

1DE WB one-dimensional gel electrophoresis

2C two-cell embryo

2DE two-dimensional gel electrophoresis

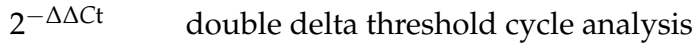

$3^{\prime}$-UTR the three prime untranslated region

$4 \mathrm{C}$ four-cell embryo

8C eight-cell embryo

ACT activation mannitol medium

CaMKII $\quad \mathrm{Ca}^{2+} /$ calmodulin-dependent protein kinase II

ANOVA analysis of variance

BL blastocyst

bp base pair

BSA bovine serium albumin

CDC20 cell-division cycle protein 20

CDH1 cadherin-1

cDNA complementary deoxyribonucleic acid

CHAPS 3-[(3-Cholamidopropyl)dimethylammonio]-1-propanesulfonate

c-mos protein of mos proto-oncogene

COCs cumulus-oocyte complexes

CPE cytoplasmic polyadenylation element

CPEB1 cytoplasmic polyadenylation element-binding protein 1

CPEB2 cytoplasmic polyadenylation element-binding protein 2

CPEB3 cytoplasmic polyadenylation element-binding protein 3

CPEB4 cytoplasmic polyadenylation element-binding protein 4

CPEBs cytoplasmic polyadenylation element binding proteins

CSF cytostatic factor

CTR control

DAPI 2-(4-amidinofenyl)-1H-indol-6-carb

dbcAMP N6,2'-O-Dibutyryladenosine $3^{\prime}, 5^{\prime}$-cyclic monophosphate sodium salt

DNA deoxyribonucleic acid

dsRNA double-stranded ribonucleic acid

ECL chemiluminescent reagent

eEF2 eukaryotic elongation factor 2

GAPDH glyceraldehyde-3-phosphate dehydrogenase

GV germinal vesicle

GVBD germinal vesicle breakdown

HIF- $1 \alpha$ hypoxia-inducible factor- $1 \alpha$

ICC immunocytochemistry

IEF isoelectric focusing separation

IgG immunoglobulin G

KD knockdown

KO knockout

LSD least significant difference

M marker

MAPK mitogen-activated protein kinases

MI metaphase I

MII metaphase II

MO morula

MPF maturation promoting factor

mRNA messenger ribonucleic acid

NC negative control

NCBI National Center for Biotechnology 


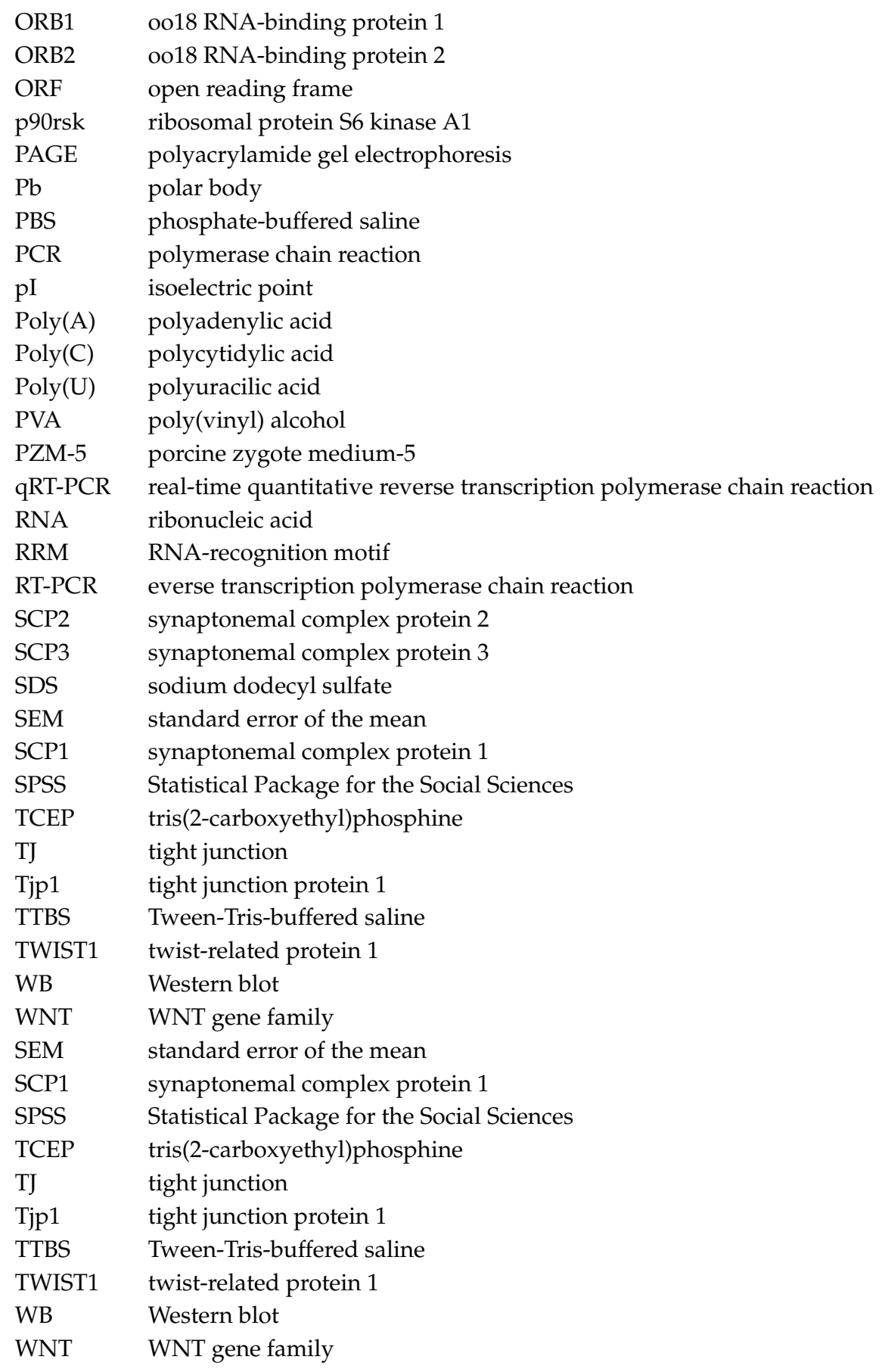

\section{References}

1. Belloc, E.; Pique, M.; Mendez, R. Sequential waves of polyadenylation and deadenylation define a translation circuit that drives meiotic progression. Biochem. Soc. Trans. 2008, 36, 665-670. [CrossRef] [PubMed]

2. Huarte, J.; Stutz, A.; O'Connell, M.L.; Gubler, P.; Belin, D.; Darrow, A.L.; Strickland, S.; Vassalli, J.D. Transient translational silencing by reversible mRNA deadenylation. Cell 1992, 69, 1021-1030. [CrossRef]

3. Liang, C.; Su, Y.; Fan, H.; Schatten, H.; Sun, Q. Mechanisms Regulating Oocyte Meiotic Resumption: Roles of Mitogen-Activated Protein Kinase. Mol. Endocrinol. 2007, 21, 2037-2055. [CrossRef] [PubMed]

4. Nagaike, T.; Manley, J.L. Transcriptional activators enhance polyadenylation precursors of mRNA. RNA Biol. 2011, 8, 964-967. [CrossRef] [PubMed]

5. Proudfoot, N.J. Ending the message: Poly(A) signals then and now. Genes Dev. 2011, 25, 1770-1782. [CrossRef] [PubMed] 
6. Eckmann, C.R.; Rammelt, C.; Wahle, E. Control of poly(A) tail length. Wiley Interdiscip. Rev. RNA 2011, 3, 348-361. [CrossRef] [PubMed]

7. Osborne, H.B.; Richter, J.D. Translational control by polyadenylation during early development. Prog. Mol. Subcell. Biol. 1997, 18, 173-198. [PubMed]

8. Duranthon, V.; Renard, J.-P. Storage and functional recovery of molecules in oocyte. In Biology and Pathology of the Oocyte: Its Role in Fertility and Reproductive Medicine; Trounson, A.O., Gosden, R.D., Eds.; Cambridge University Press: Cambridge, UK, 2003; pp. 81-112. ISBN 0-521-79958-9.

9. Kang, M.K.; Han, S.J. Post-transcriptional and post-translational regulation during mouse oocyte maturation. BMB Rep. 2011, 44, 147-157. [CrossRef] [PubMed]

10. Hake, L.E.; Richter, J.D. CPEB is a specificity factor that mediates cytoplasmic polyadenylation during Xenopus oocyte maturation. Cell 1994, 79, 617-627. [CrossRef]

11. Du, L.; Richter, J.D. Activity-dependent polyadenylation in neurons. RNA 2005, 11, 1340-1347. [CrossRef] [PubMed]

12. Mendez, R.; Richter, J.D. Translational control by CPEB: A means to the end. Nat. Rev. Mol. Cell Biol. 2001, 2, 521-529. [CrossRef] [PubMed]

13. Huang, Y.S.; Kan, M.C.; Lin, C.L.; Richter, J.D. CPEB3 and CPEB4 in neurons: Analysis of RNA-binding specificity and translational control of AMPA receptor GluR2 mRNA. EMBO J. 2006, 25, 4865-4876. [CrossRef] [PubMed]

14. Theis, M.; Si, K.; Kandel, E.R. Two previously undescribed members of the mouse CPEB family of genes and their inducible expression in the principal cell layers of the hippocampus. Proc. Natl. Acad. Sci. USA 2003, 100, 9602-72003. [CrossRef] [PubMed]

15. Wang, X.P.; Cooper, N.G. Comparative in Silico Analyses of Cpeb1-4 with Functional predictions. Bioinform. Biol. Insights 2010, 4, 61-83. [CrossRef] [PubMed]

16. Wu, L.; Wells, D.; Tay, J.; Mendis, D.; Abott, M.A.; Barnitt, A.; Quinlan, E.; Heynen, A.; Fallon, J.R.; Richter, J.D. CPEB-mediated cytoplasmic polyadenylation and the regulation of experience-dependent translation of $\alpha$-CaMKII mRNA at synapses. Neuron 1998, 21, 1129-1139. [CrossRef]

17. Hochegger, H.; Klotzbücher, A.; Kirk, J.; Howell, M.; le Guellec, K.; Fletcher, K.; Duncan, T.; Sohail, M.; Hunt, T. New B-type cyclin synthesis is required between meiosis I and II during Xenopus oocyte maturation. Development 2001, 128, 3795-3807. [PubMed]

18. Kim, K.C.; Oha, W.J.; Koa, K.H.; Shinb, C.Y.; Wells, D.G. Cyclin B1 expression regulated by cytoplasmic polyadenylation element binding protein in astrocytes. J. Neurosci. 2011, 31, 12118-12128. [CrossRef] [PubMed]

19. Mendez, R.; Barnard, D.; Richter, J.D. Differential mRNA translation and meiotic progression require Cdc2-mediated CPEB destruction. EMBO J. 2002, 21, 1833-1844. [CrossRef] [PubMed]

20. Minshull, J.; Blow, J.J.; Hunt, T. Translation of cyclin mRNA is necessary for extracts of activated Xenopus eggs to enter mitosis. Cell 1989, 56, 947-956. [CrossRef]

21. Murray, A.W.; Kirschner, M.W. Cyclin synthesis drives the early embryonic cell cycle. Nature 1989, 339, 275-280. [CrossRef] [PubMed]

22. Novoa, I.; Gallego, J.; Ferreira, P.G.; Mendez, R. Mitotic cell-cycle progression is regulated by CPEB1 and CPEB4-dependent translational control. Nat. Cell Biol. 2010, 12, 447-456. [CrossRef] [PubMed]

23. Hägelle, S.; Kühn, U.; Böning, M.; Katschinski, D.M. Cytoplasmic polyadenylation-element-binding protein (CPEB) 1 and 2 bind to the HIF-1 $\alpha$ mRNA 3 -UTR and modulate HIF- $1 \alpha$ protein expression. Biochem. J. 2009, 417, 235-246. [CrossRef] [PubMed]

24. Turimella, S.L.; Bedner, P.; Skubal, M.; Vangoor, V.R.; Kaczmarczyk, L.; Karl, K.; Zoidl, G.; Gieselmann, V.; Seifert, G.; Steinhauser, C.; et al. Characterization of cytoplasmic polyadenylation element binding 2 protein expression and its RNA binding activity. Hippocampus 2014. [CrossRef] [PubMed]

25. Chen, P.J.; Huang, Y.S. CPEB2-eEF2 interaction impedes HIF-1 $\alpha$ RNA translation. EMBO J. 2012, 31, $959-971$. [CrossRef] [PubMed]

26. Jansova, D.; Tetkova, A.; Koncicka, M.; Kubelka, M.; Susor, A. Localization of RNA and translation in the mammalian oocyte and embryo. PLoS ONE 2018, 13, e0192544. [CrossRef] [PubMed]

27. Kurihara, Y.; Tokuriki, M.; Myojin, R.; Hori, T.; Kuroiwa, A.; Matsuda, Y.; Sakurai, T.; Kimura, M.; Hecht, N.B.; Uesugi, S. CPEB2, A Novel Putative Translational Regulator in Mouse Haploid Germ Cells. Biol. Reprod. 2003, 69, 261-268. [CrossRef] [PubMed] 
28. Johnson, R.M.; Vu, N.T.; Griffin, B.P.; Gentry, A.E.; Archer, K.J. Chalfant CE5, Park MA6The alternative splicing of cytoplasmic polyadenylation element binding protein 2 drives anoikis resistance and the metastasis of triple negative breast cancer. J. Biol. Chem. 2015, 290, 25717-25727. [CrossRef] [PubMed]

29. Sus Scrofa Cytoplasmic Polyadenylation Element Binding Protein 2 Variant A. (CPEB2) mRNA, Complete CDS. Available online: https:/ / www.ncbi.nlm.nih.gov/nuccore/HM037344.1 (accessed on 24 March 2010).

30. Sus Scrofa Cytoplasmic Polyadenylation Element Binding Protein 2 Variant B. (CPEB2) mRNA, Complete CDS. Available online: https:/ / www.ncbi.nlm.nih.gov/nuccore/HM037345.1 (accessed on 28 March 2010).

31. Afroz, T.; Skrisovska, L.; Belloc, E.; Guillén-Boixet, J.; Méndez, R.; Allain, F.H. A fly trap mechanism provides sequence-specific RNA recognition by CPEB proteins. Genes Dev. 2014, 28, 1498-1514. [CrossRef] [PubMed]

32. Eliscovich, C.; Peset, I.; Vernos, I.; Méndez, R. Spindle-localized CPE-mediated translation controls meiotic chromosome segregation. Nat. Cell Biol. 2008, 10, 858-865. [CrossRef] [PubMed]

33. Fernández-Miranda, G.; Méndez, R. The CPEB-family of proteins, translational control in senescence and cancer. Ageing Res. Rev. 2012, 11, 460-472. [CrossRef] [PubMed]

34. Groisman, I.; Huang, Y.S.; Mendez, R.; Cao, Q.; Theurkauf, W.; Richter, J.D. CPEB, Maskin, and Cyclin B1 mRNA at the Mitotic Apparatus. Cell 2000, 103, 435-447. [CrossRef]

35. Macnicol, M.C.; Cragle, C.E.; Arumugam, K.; Fosso, B.; Pesole, G.; MacNicol, A.M. Functional Integration of mRNA Translational Control Programs. Biomolecules 2015, 5, 1580-1599. [CrossRef] [PubMed]

36. Richter, J.D. CPEB: A life in translation. Trends Biochem. Sci. 2007, 32, 279-285. [CrossRef] [PubMed]

37. Lai, Y.T.; Su, C.K.; Jiang, S.T.; Chang, Y.J.; Lai, A.C.; Huang, Y.S. Deficiency of CPEB2-Confined Choline Acetyltransferase Expression in the Dorsal Motor Nucleus of Vagus Causes Hyperactivated Parasympathetic Signaling-Associated Bronchoconstriction. J. Neurosci. 2016, 36, 12661-12676. [CrossRef] [PubMed]

38. Komrskova, P.; Susor, A.; Malik, R.; Prochazkova, B.; Liskova, L.; Supolikova, J.; Hladky, S.; Kubelka, M. Aurora Kinase A Is Not Involved in CPEB1 Phosphorylation and cyclin B1 mRNA Polyadenylation during Meiotic Maturation of Porcine Oocytes. PLoS ONE 2014, 9, e101222. [CrossRef] [PubMed]

39. Jarrell, V.L.; Day, B.N.; Prather, R.S. The Transition from Maternal to Zygotic Control of Development Occurs during the 4-Cell Stage in the Domestic Pig, Sus scrofa: Quantitative and Qualitative Aspects of Protein Synthesis. Biol. Reprod. 1991, 44, 62-68. [CrossRef] [PubMed]

40. Kan, M.C.; Oruganty-Das, A.; Cooper-Morgan, A.; Jin, G.; Swanger, S.A.; Bassell, G.J.; Florman, H.; van Leyen, K.; Richter, J.D. CPEB4 is a cell survival protein retained in the nucleus upon ischemia or endoplasmic reticulum calcium depletion. Mol. Cell. Biol. 2010, 30, 5658-5671. [CrossRef] [PubMed]

41. Kundel, M.; Jones, K.J.; Shin, C.Y.; Wells, D.G. Cellular/Molecular Cytoplasmic Polyadenylation Element-Binding Protein Regulates Neurotrophin-3-Dependent $\beta$-Catenin mRNA Translation in Developing Hippocampal Neurons. J. Neurosci. 2009, 29, 13630-13639. [CrossRef] [PubMed]

42. Clevers, H.; Nusse, R. Wnt/ $\beta$-Catenin Signaling, Disease, and Emerging Therapeutic Modalities. Cell 2017, 169, 985-999. [CrossRef]

43. Kumar, M.; Camlin, N.J.; Holt, J.E.; Teixeira, J.M.; McLaughlin, E.A.; Tanwar, P.S. Germ cell specific overactivation of WNT/ $\beta$ catenin signalling has no effect on folliculogenesis but causes fertility defects due to abnormal foetal development. Sci. Rep. 2016, 6. [CrossRef] [PubMed]

44. Fan, H.Y.; Huo, L.J.; Meng, X.Q.; Zhong, Z.S.; Hou, Y.; Chen, D.Y.; Sun, Q.Y. Involvement of Calcium/Calmodulin-Dependent Protein Kinase II (CaMKII) in Meiotic Maturation and Activation of Pig Oocytes1. Biol. Reprod. 2003, 69, 1552-1564. [CrossRef] [PubMed]

45. Tay, J.; Richter, J.D. Germ Cell Differentiation and Synaptonemal Complex Formation Are Disrupted in CPEB Knockout Mice. Dev. Cell 2001, 1, 201-213. [CrossRef]

46. Racki, W.J.; Richter, J.D. CPEB controls oocyte growth and follicle development in the mouse. Development 2006, 133, 4527-4537. [CrossRef] [PubMed]

47. Stebbins-Boaz, B.; Hake, L.E.; Richter, J.D. CPEB controls the cytoplasmic polyadenylation of cyclin, Cdk2 and c-mos mRNAs and is necessary for oocyte maturation in Xenopus. EMBO J. 1996, 15, 2582-2592. [CrossRef] [PubMed]

48. Prochazkova, B.; Institute for Research in Biomedicine, Barcelona, Spain. Personal communication, 2016.

49. Nairismägi, M.L.; Vislovukh, A.; Meng, Q.; Kratassiouk, G.; Beldiman, C.; Petretich, M.; Groisman, R.; Füchtbauer, E.M.; Harel-Bellan, A.; Groisman, I. Translational control of TWIST1 expression in MCF-10A cell lines recapitulating breast cancer progression. Oncogene 2012, 31, 4960-4966. [CrossRef] [PubMed] 
50. Fuchtbauer, E.M. Expression of M-Twist During Postimplantation Development of the Mouse. Dev. Dyn. 1995, 204, 316-322. [CrossRef] [PubMed]

51. Gitelman, I. Twist Protein in Mouse Embryogenesis. Dev. Biol. 1997, 189, 205-214. [CrossRef] [PubMed]

52. Matter, K.; Aijaz, S.; Tsapara, A.; Balda, M.S. Mammalian tight junctions in the regulation of epithelial differentiation and proliferation. Curr. Opin. Cell Biol. 2005, 17, 453-458. [CrossRef] [PubMed]

53. Nagaoka, K.; Udagawa, T.; Richter, J.D. CPEB-mediated ZO-1 mRNA localization is required for epithelial tight-junction assembly and cell polarity. Nat. Commun. 2012, 3. [CrossRef] [PubMed]

54. Hartsock, A.; Nelson, W.J. Adherens and Tight Junctions: Structure, Function and Connections to the Actin Cytoskeleton. Biochim. Biophys. Acta 2008, 1778, 660-669. [CrossRef] [PubMed]

55. Livak, K.J.; Schmittgen, T.D. Analysis of Relative Gene Expression Data Using Real-Time Quantitative PCR and the $2^{-\Delta \Delta C t}$ Method. Methods 2001, 25, 402-408. [CrossRef] [PubMed]

(C) 2018 by the authors. Licensee MDPI, Basel, Switzerland. This article is an open access article distributed under the terms and conditions of the Creative Commons Attribution (CC BY) license (http://creativecommons.org/licenses/by/4.0/). 